\title{
COVID-19 and Influenza Coexistence
}

\section{COViD-19 ve İnfluenza Birlikteliği}

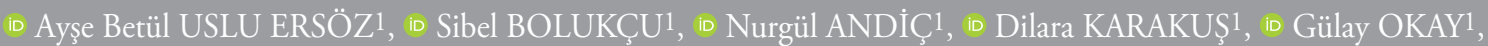 \\ (i) Bilge SÜMBÜL2, id Asiye Bahar KAÇMAZ3, id Bülent DURDU1, id Yasemin AKKOYUNLU1, id Meliha MERIÇ KOÇ1}

${ }^{1}$ Bezmialem Vakıf University Faculty of Medicine, Department of Infectious Diseases and Clinical Microbiology, İstanbul, Turkey

${ }^{2}$ Bezmialem Vakıf University Faculty of Medicine, Department of Medical Microbiology, İstanbul, Turkey

${ }^{3}$ Bezmialem Vakıf University, Dragos Hospital, Clinic of Infectious Diseases and Clinical Microbiology, İstanbul, Turkey

\section{ABSTRACT}

Objective: Viral pneumonia cases occur quite frequently in the community. The rate of viral infections in community-acquired pneumonia is about $25 \%$. severe acute respiratory syndrome coronavirus-2 (SARS-CoV-2) and influenza are also viruses that can cause pneumonia. In this study, we aimed to determine the rate of influenza co-infection in Coronavirus disease-19 (COVID-19) cases.

Methods: The data of adult patients who applied to Bezmialem Vakıf University Hospital between March 6, 2020, and May 21, 2020, which were positive with the SARS-CoV-2 polymerase chain reaction (PCR) test and influenza antigen test were retrospectively scanned from the hospital automation system.

Results: SARS-CoV-2 PCR test was found positive in 498 adult patients who applied to our hospital. Two hundrend-sixty of these patients were hospitalized and 238 were followed up on an outpatient basis. In 88 patients SARS-CoV-2 PCR and influenza antigen were studied, and 6 of them had positive influenza antigen. COVID-19 and influenza co-infection was not detected.

Conclusion: In order to determine the exact rate of influenza and COVID-19 co-infection, it is necessary to evaluate the patients who applied with the appropriate clinical picture from the beginning of the seasonal influenza period by using reverse transcription-PCR for these two viral infections, if possible. Further research is needed in this area.

Keywords: COVID-19, influenza, co-infection

\section{ÖZ}

Amaç: Viral pnömoniler toplumda oldukça sık görülür. Toplum kökenli pnömonide viral enfeksiyonların oranı yaklaşık \%25'tir. Şiddetli akut solunum yolu enfeksiyonu-2 (SARS-CoV-2) ve influenza da pnömoniye neden olabilen virüslerdendir. Bu çalışmada Koronavirüs hastalığı-19 (COVİD-19) olgularında influenza koenfeksiyonu oranını belirlemeyi amaçladık.

Yöntemler: 6 Mart 2020-21 Mayıs 2020 tarihleri arasında Bezmialem Vakıf Üniversitesi Hastanesi'ne başvuran, SARS-CoV-2 polimeraz zincir reaksiyonu (PZR) testi ve influenza antijen testi pozitif olarak sonuçlanan erişkin hastaların verileri retrospektif olarak hastane otomasyon sisteminden tarandi.

Bulgular: Hastanemize başvurmuş olan erişkin hastaların 498'inde SARS-CoV-2 PZR testi pozitif bulundu. Bu hastaların 260'ı hastaneye yatırılarak, 238'i ayaktan takip edilen hastalardı. SARS-CoV-2 PZR ve influenza antijeni çalışılmış olan toplam 88 hasta mevcuttu ve bunların $45^{\prime}$ inde influenza antijeni pozitifti. COVİ-19 ve influenza ko-infeksiyonu saptanmad.

Sonuç: İnfluenza ve COVID-19 ko-enfeksiyonu oranını tam olarak belirlemek için mevsimsel influenza döneminin başından itibaren uygun klinik tablo ile başvuran hastaları bu iki viral enfeksiyon yönünden mümkünse gerçek zamanlı-PZR ile değerlendirmek gereklidir. Bu alanda daha fazla çalışmaya ihtiyaç vardır.

Anahtar Sözcükler: COVİD-19, influenza, ko-enfeksiyon 


\section{Introduction}

Viral pneumonia cases are quite common in the community. The rate of viral infections in community-acquired pneumonia is approximately $25 \%$ (1). Severe acute respiratory syndrome coronavirus-2 (SARS-CoV-2) and influenza are viruses that can cause pneumonia $(2,3)$. Seasonal influenza is a public health problem affecting approximately $5-10 \%$ of adults worldwide each year and is responsible for significant morbidity and mortality, especially in high-risk groups (4). Patients with influenza infection generally present with cough, fever, headache, weakness, muscle pain, runny nose, and sweating. Patients without influenza pneumonia tend to have the same symptoms, but dyspnea is more common in patients with pneumonia (3).

Ground glass opacities, consolidation, and nodular opacities can be seen in the thorax computed tomography (CT) of patients with viral pneumonia. Generally, patients present with weak opacities defined as ground glass. The second most common finding is consolidation. Nodular opacities are less common. Opacities are usually unevenly distributed and bilateral involvement is quite common (3).

In Coronavirus disease-19 (COVID-19) patients, the most common symptoms are fever, weakness, and dry cough, followed by other symptoms such as headache, nasal congestion, sore throat, myalgia, and arthralgia. Some patients may experience shortness of breath usually accompanied by hypoxemia in the second week of the illness (5).

86.2\% of COVID-19 patients have abnormal findings on thoracic CT images, and more than $75 \%$ of these findings are in the form of bilateral lung involvement with a peripheral distribution. In mild patients, ground-glass opacities that were initially unilateral and focal gradually progress to bilateral or multilobular lesions. As the disease progresses, ground-glass opacities turn into consolidations (6).

In Turkey, influenza infections are most common between November and March (4). The first COVID-19 case in Turkey was detected on March 10, 2020 (7). Clinical findings, routes of transmission, and thoracic CT findings are similar in both viral infections. The coincidence of the COVID-19 pandemic with seasonal influenza also suggests the possibility of coinfection. There are various publications about the coexistence of COVID-19 and other respiratory viruses (8-10). The aim of this study was to determine the rate of influenza co-infection in the COVID-19 cases we followed-up.

\section{Method}

Between March 6, 2020 and May 21, 2020, patients admitted to Bezmialem Vakıf University with symptoms suggesting COVID-19 infection were included. Combined nasal and pharyngeal swabs were obtained and studied with SARS-CoV-2 reverse transcription-polymerase chain reaction (RT-PCR) test using Biospeedy COVID-19 SARS-CoV-2 qPCR Detection Kit (Bioeksen, Turkey). For influenza diagnosis, nasopharyngeal swab samples were obtained, and an influenza antigen test was performed with ichroma TRIAS Influenza A+B (Boditech, Kore) test kit using ichroma II device. During the pandemic period, the data of adult patients whose SARS-CoV-2 PCR test and influenza antigen test were positive were retrospectively scanned from the hospital automation system.

\section{Results}

The SARS-CoV-2 PCR test was found to be positive in 498 of the adult patients who applied to our hospital between March 6, 2020, and May 21, 2020. Two hundred and sixty of these patients were hospitalized and 238 were outpatients.

Influenza antigen was found positive in 45 (21\%) of 212 adult patients whose influenza antigen was studied. Seven of the cases were influenza A positive, and 38 of them were influenza B positive.

During the pandemic, both SARS-CoV-2 PCR and influenza antigen were studied in 82 patients. The average age of these patients was $54.45 \pm 16.6$ and $50 \%(n=44)$ of them were males. All of those were hospitalized patients. Thoracic CT findings were found to be compatible with viral pneumonia in 82 of 88 patients. CT findings of 17 patients were mild, and the CT findings of 65 patients were moderate/severe. However, COVID-19 and influenza co-infection were not detected in any patient.

\section{Discussion}

Influenza viruses are known to cause many pandemics. Although there are 3 different influenza viruses -A, B, and C-antigenically, influenza $A$ virus is responsible for the vast majority of mortality and morbidity in humans (11). In 1918, the influenza A/H1N1 (Spanish flu) pandemic killed nearly 40 million people worldwide (11). In 2009, a new pig-derived H1N1 strain was identified in Mexico. In June 2009, the World Health Organization (WHO) declared the beginning of this epidemic and reported a total of 18,631 deaths with confirmed H1N1pdm09 disease (12). In 2012, WHO confirmed 610 cases infected with the influenza A/ $\mathrm{H} 5 \mathrm{~N} 1$ virus. Most of these cases had close contact with infected birds, and 360 mortality occurred (11). Influenza B virus, unlike influenza $\mathrm{A}$, almost exclusively infects humans and is therefore not associated with a pandemic. Also, influenza B is less diverse as it undergoes slower antigenic drift (4).

In Turkey, influenza infections are most common during November-March (4). A study conducted in Turkey between 2003 and 2016 found that except 2009-2010 pandemic, an average of $32 \%$ of influenza cases was associated with influenza B (4).

The SARS-CoV-2 virus caused a pandemic that started in Wuhan, China in December 2019 and spread to the whole world (5). To date (27.06.2020), 491.128 deaths have been reported worldwide by WHO (13). In Turkey, the first COVID-19 case was seen on March 10, 2020, (7) and COVID-19 so far (06.27.2020) caused the deaths of 5,065 patients (13). 
Diseases caused by influenza and SARS-CoV-2 virus have similar characteristics and their seasonal preferences coincide which suggested the possibility of these infections being seen together. Our aim was to determine the rate of this coincidence.

In the literature, rates of influenza co-infection in COVID-19 case series vary between $0-5 \%(8-10,15-17)$. We didn't detect any influenza and COVID-19 co-infection. We think this may be due to three factors. In Turkey, COVID-19 cases first appeared at the end of the influenza season. Also, measures to prevent COVID-19 might have prevented the transmission of influenza. In addition, the lower sensitivity of the influenza antigen test (75.6\% for influenza A, $63.6 \%$ for influenza B) (14) we used for the diagnosis of influenza compared to the RT-PCR method may have led to the absence of any co-infected patients.

\section{Conclusion}

In conclusion, in order to determine the rate of influenza and COVID-19 co-infection precisely, patients presenting with an appropriate clinical picture from the beginning of the seasonal influenza period should be evaluated with RT-PCR for these two viral infections, if possible. Further studies on this subject are required.

\section{Ethics}

Ethics Committee Approval: Bezmialem Vakıf University Clinical Research Ethics Committee (no: 71306642-050.05.04-)

Informed Consent: Retrospective study.

Peer-review: Externally peer reviewed.

\section{Authorship Contributions}

Concept: A.B.U.E., S.B., N.A., D.K., G.O., B.S., A.B.K., B.D., Y.A., M.M.K., Design: A.B.U.E., S.B., N.A., D.K., G.O., B.S., A.B.K., B.D., Y.A., M.M.K., Data Collection or Processing: A.B.U.E., S.B., N.A., D.K., G.O., B.S., A.B.K., B.D., Y.A., M.M.K., Analysis or Interpretation: A.B.U.E., S.B., N.A., D.K., G.O., B.S., A.B.K., B.D., Y.A., M.M.K., Literature Search: A.B.U.E., S.B., N.A., D.K., G.O., B.S., A.B.K., B.D., Y.A., M.M.K., Writing: A.B.U.E., S.B., N.A., D.K., G.O., B.S., A.B.K., B.D., Y.A., M.M.K.

Conflict of Interest: No conflict of interest was declared by the authors.

Financial Disclosure: This work was supported by Elsevier Publications.

\section{References}

1. Burk M, El-Kersh K, Saad M, Wiemken T, Ramirez J, Cavallazzi R. Viral infection in community-acquired pneumonia: A systematic review and meta-analysis. Eur Respir Rev 2016;25:178-88.

2. Guan WJ, Ni ZY, Hu Y, Liang WH, Ou CQ, He JX, et al. Clinical characteristics of coronavirus disease 2019 in China. N Engl J Med 2020;382:1708-20.
3. Cavallazzi R, Ramirez JA. Influenza and viral pneumonia. Clin Chest Med 2018;39:703-21.

4. Meşe S, Uyanik A, Özakay A, Öztürk S, Badur S. Influenza surveillance in western Turkey in the era of quadrivalent vaccines: A 2003-2016 retrospective analysis. Hum Vaccin Immunother 2018;14:1899-908.

5. Zhou M, Zhang X, Qu J. Coronavirus disease 2019 (COVID-19): A clinical update. Front Med 2020;14:126-35.

6. Guan WJ, Ni ZY, Hu Y, Liang WH, Ou CQ, He JX, et al. Clinical characteristics of coronavirus disease 2019 in China. N Engl J Med 2020;382:1708-20.

7. Hasöksüz M, Kiliç S, Saraç F. Coronaviruses and SARS-COV-2. Turk J Med Sci 2020;50:549-56.

8. Kim D, Quinn J, Pinsky B, Shah NH, Brown I. Rates of co-infection between SARS-CoV-2 and other respiratory pathogens. JAMA 2020;323:2085-6.

9. Cuadrado-Payán E, Montagud-Marrahi E, Torres-Elorza M, Bodro $\mathrm{M}$, Blasco M, Poch E, et al. SARS-CoV-2 and influenza virus coinfection. Lancet 2020;395:84.

10. Ding Q, Lu P, Fan Y, Xia Y, Liu M. The clinical characteristics of pneumonia patients coinfected with 2019 novel coronavirus and influenza virus in Wuhan, China. J Med Virol 2020;92:1549-55.

11. Labella AM, Merel SE. Influenza. Med Clin North Am 2013;97:62145.

12. Wikramaratna PS, Gupta S. Influenza outbreaks. Cell Microbiol 2009;11:1016-24.

13. WHO. Coronavirus disease (COVID-19) Situation Report -159. Available from: https://www.who.int/docs/default-source/ coronaviruse/situation-reports/20200627-covid-19-sitrep-159. pdf?sfvrsn=93e027f6_2. Accessed 27 June 2020.

14. Yoo SJ, Shim HS, Yoon S, Moon HW. Evaluation of high-throughput digital lateral flow immunoassays for the detection of influenza A/B viruses from clinical swab samples. J Med Virol 2020;92:1040-6.

15. Wu C, Chen X, Cai Y, Xia J, Zhou X, Xu S, et al. Risk factors associated with acute respiratory distress syndrome and death in patients with coronavirus disease 2019 pneumonia in Wuhan, China. JAMA Intern Med 2020;180:934-43.

16. Arentz M, Yim E, Klaff L, Lokhandwala S, Riedo FX, Chong M, et al. Characteristics and outcomes of 21 critically Ill patients with COVID-19 in Washington State. JAMA 2020;323:1612-4.

17. Lansbury L, Lim B, Baskaran V, Lim WS. Co-infections in people with COVID-19: A systematic review and meta-analysis. J Infect 2020;81:266-75.

18. Gimferrer L, Andrés C, Rando A, Piñana M, Codina MG, Martin $\mathrm{MDC}$, et al. Evaluation of seegene allplex respiratory panel 1 kit for the detection of influenza virus and human respiratory syncytial virus. J Clin Virol 2018;105:31-4. 